International Journal of Climate Research

2021 Vol. 5, No.1, pp. 35-48.

ISSN: 2690-2796

DOI: 10.18488/journal.112.2021.51.35.48

(C) 2021 Conscientia Beam. All Rights Reserved.

check for

\title{
PARAMETRIC ANALYSIS OF RAINFALL VARIABILITY OVER SOME SELECTED LOCATIONS IN NIGERIA
}

\author{
Falaiye O. A. ${ }^{1}$ \\ Olaitan A. G. ${ }^{2}$ \\ Nwabachili S. C. ${ }^{3+}$
}

\author{
${ }^{1,2,3}$ University of Ilorin, Nigeria. \\ 'Email: sesantavo2001@vahoo.com Tel:+2348056753493 \\ ${ }^{2}$ Email: olaitanakinboadeg@gmail.com Tel: +2348134871423 \\ ${ }^{s}$ Email: samuelnwabachilis8@gmail.com Tel: +2348139124558
}

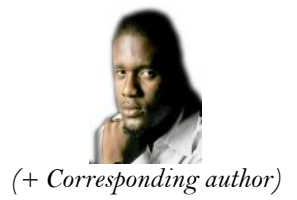

ABSTRACT

Rainfall is one meteorological parameter that affects virtually all human activities. For instance, the amount of rainfall received in an area is an important determining factor in estimating or quantifying the amount of water available to meet various demands, such as agricultural, industrial, domestic water supply, and power generation. Climate change has generally been accepted to be a result of the emission of excess greenhouse gases. It has caused an increase in flooding, severe and more frequent droughts, increase in wildfires, and heatwaves in various parts of the globe. Climate change is said to have a considerable impact on the variability in hydro-meteorological variables such as rainfall, temperature, and evaporation. In this study, we carry out a parametric analysis of rainfall variability over some selected locations in Nigeria and determine the trend using surface observation data from seven weather stations. The datasets of rainfall used in this study were acquired; from the Nigerian Meteorological Agency (NIMET) for a period of 30 years (1980 to 2010) from seven locations; which are Abuja, Enugu, Ikeja, Ilorin, Maiduguri, Port Harcourt, and Sokoto, representing the six geographical zones of Nigeria. The results gotten showed an upward movement in the trend line which indicated an increase in the amount of rainfall received by the study areas. While some Cities (Maiduguri, Sokoto) received a large increase in the amount of rainfall received yearly, others received a slight increase such as Lagos, Port Harcourt, Ilorin, Abuja and Enugu

Contribution/Originality: This study contributes to the existing literature about the evidence of variability in rainfall across Nigeria. This study will therefore help the government to introduce policies that will help in cushioning the effects of climate change as regards agriculture and land usage.

\section{INTRODUCTION}

Climate change and variability impact have been studied and reported worldwide and more studies are currently going on [1]. Climate change has generally been accepted to be as a result of the emission of excess greenhouse gases. It has caused an increase in flooding, severe and more frequent droughts, increase in wildfires, and heatwaves in various parts of the globe [2]. There is said to be a considerable impact of climate change on the variability of hydro meteorological variables such as rainfall, temperature, and evaporation [3], [4], [5]. From the mentioned parameters, rainfall is said to be the most important component of the water cycle and its variability is closely related to drought and flood. These can threaten the supply of water, irrigation for agricultural purpose and the socio-economic development [6], [7]. As reported by the Intergovernmental Panel on Climate Change (IPCC), 
rainfall-induced hazards have become more intense and frequent over the past decade which is caused by anthropogenic influence [8]. Due to increased concern about climate change, climate data is becoming of paramount importance to the scientific community and society as decisions by citizens, businesses and governments depend on the availability and correct interpretation of this data [9]. Besides rainfall and temperature fluctuations, increasing occurrence of extreme events such as droughts, floods, and heavy storms in Africa are cited as important characteristics of climate variability [10]. Rainfall is one meteorological parameter that affects virtually all human activities. For instance, the amount of rainfall received in an area is an important factor for the quantifying of the amount of water available to meet various demands, such as agricultural, industrial, domestic water supply, and power generation [11]. It is therefore beneficial to emphasize that researches on rainfall variability are crucial in reducing the consequences of extreme climate hazards such as droughts and floods. This is because the quantity of water present in the soil, which is utilized by crops, is dependent on some important rainfall characteristics such as onset, length, and cessation, which influence the success or failure of the cropping season [12], [13]. Several studies including Intergovernmental Panel on Climate Change [14], [15], [16] have shown temperature and fluctuation in rainfall frequency and intensity experienced a rise. This is said to pose a great challenge to peasant farmers in a lot of countries. African Countries, especially those in West Africa; are said to be more prone to the impact of climate change [17]. This is therefore said to be a result of their considerable dependence on rain-fed agriculture, also their poverty that leaves them vulnerable to climate stress. Findings from the Fifth Assessment Report of the IPCC indicate that although the West African monsoon winds are likely to weaken, there will very likely be an intensification of monsoon precipitation which is a result of an increase in atmospheric moisture. However, the report stresses that monsoon retreat dates will be delayed thereby increasing the length of the monsoon season [18].

This study aims to assess the parametric analysis of rainfall variability over some selected stations in Nigeria. This is going to be achieved by determining the variation in rainfall patterns in the study areas, by using the annual and monthly mean deviation.

\section{METHODOLOGY}

2.1. Study Areas

\subsubsection{Port Harcourt}

Port Harcourt is the Capital city of Rivers State, Nigeria. It is located at latitude $4^{\circ} 49^{\prime} 27^{\prime \prime} \mathrm{N}$, and longitude $7^{\circ}$ 2' o" E [19], [20]. Port Harcourt experiences heavy rainfall of about 2369.06mm, valid for the year 1931-2014 [21]. The rainy season lasts for about eight months (March to October), and the so-called dry months are not free from occasional rainfall [22].

2.1.2. Abuja

Abuja the capital of Nigeria lies at latitude $9^{\circ} 4^{\prime} 20^{\prime \prime} \mathrm{N}$, longitude $7^{\circ} 29^{\prime} 28^{\prime \prime} \mathrm{E}$, and an elevation of $840 \mathrm{~m}(2760$ $\mathrm{ft}$ ) above sea level. The city is located in the Federal Capital Territory (FCT) whose land area is about $8000 \mathrm{~km}^{2}$ [23]. Abuja has two (2) distinct seasons namely: rainy season which occurs 6 - 7 months (April to October), amount ranging from 1558 to $1682 \mathrm{~mm}(1986-2016)$, with temperature measuring up to $40^{\circ} \mathrm{C}$ in May. The dry season lasts about 5 to 6 months (November to March) with dry winds which reduces the temperature to as low as $12^{\circ} \mathrm{C}[24],[23]$.

\subsubsection{Ikeja}

Ikeja, which is the capital city of Lagos Nigeria. It is located at latitude $6^{\circ} 36^{\prime} 21$ " $\mathrm{N}$ and longitude $3^{\circ} 20^{\prime} 56^{\prime \prime} \mathrm{E}$. It has an annual average temperature of $23.0^{\circ} \mathrm{C}\left(73.4^{\circ} \mathrm{F}\right)$. The warmest months are from February to April, where 
daytime temperatures can exceed $29^{\circ} \mathrm{C}\left(84.2^{\circ} \mathrm{F}\right)$. Rainfall season usually throughout the year with mean annual rainfall ranging between $1,500 \mathrm{~mm}$ and $2,300 \mathrm{~mm}(1996-2014)$ [25].

\subsubsection{Maiduguri}

Maiduguri is the capital of Borno State is located at latitude $11^{\circ} 49^{\prime} 51^{\prime \prime} \mathrm{N}$ and longitude $13^{\circ} 9^{\prime} 3^{\prime \prime}$ E. It is characterized by two major seasons wet and dry. The wet season lasts for 7 months (April to October) with a peak during the months of July and August. The average annual rainfall is $552.1 \mathrm{~mm}$. Average yearly maximum temperature is about $35.2^{\circ} \mathrm{C}$ while the minimum temperature is about $19.9^{\circ} \mathrm{C}$ [26].

\subsubsection{Enugu}

Enugu is located approximately at latitude $6^{\circ} 27^{\prime} 35^{\prime \prime} \mathrm{N}$ and longitude $7^{\circ} 32^{\prime} 56^{\prime \prime} \mathrm{E}$ [26] and is the capital city of Enugu state. It is situated on the eastern fringe of Udi escarpment at a height of about $223 \mathrm{~m}$ above sea level. As a result of Enugu being located in the tropics, it is characterized by high radiation all year around. Enugu records a mean daily temperature of $26.7^{\circ} \mathrm{C}\left(80.1^{\circ} \mathrm{F}\right)$ and a mean annual rainfall of $2000 \mathrm{~mm}(2000-2013)$ [27], [28].

\subsubsection{Ilorin}

Ilorin, the capital city of Kwara State, Nigeria, is located on latitude $8^{\circ} 29^{\prime} 47^{\prime \prime} \mathrm{N}$ and longitude $4^{\circ} 32^{\prime} 30^{\prime \prime E}$. The climate of Ilorin is characterized by both wet and dry seasons. The temperature in Ilorin ranges from $33^{\circ} \mathrm{C}$ to $34^{\circ} \mathrm{C}$ from November to January, while from February to April; the value ranges between $34^{\circ} \mathrm{C}$ to $53^{\circ} \mathrm{C}$. The monthly mean temperatures are very high varying from $25.0^{\circ} \mathrm{C}$ to $28.9^{\circ} \mathrm{C}$. The total amount of annual rainfall in the area is about $1200 \mathrm{~mm}(1971-2000)[29]$.

\subsection{Dataset Used}

The dataset of rainfall used in this study was acquired from the Nigerian Meteorological Agency (NIMET). For the cities of Enugu, Abuja, Enugu, Ikeja, Ilorin, Maiduguri, Port Harcourt, data for the total of 31 years (1980 2010) was collected, and for Sokoto, data for the total of 29 years (1982 - 2010). These cities represent the six geographical zones of Nigeria. The summary of the data collected is shown in Table 1. In this study, we study the parametric analysis (trend analysis) of rainfall variability over some selected locations in Nigeria and determine the trend using surface observation data from seven weather stations, (one station from each of the six geopolitical zones in Nigeria). The stations used for this study is highlighted in the Figure 1.

\subsection{Data Analysis}

The dataset used is aided using Microsoft Excel and the Python programming language. The descriptive statistics used to consist of the standard deviation, the linear regression for the analyses of the study. The descriptive statistic is used to make the data presentation organized and provides concise information to make the analysis easier. A simple formula can be used to compute the standard deviation; this standard deviation can then easily be compared with different observation. In this study, the standard deviation was achieved by using Microsoft excel. Linear regression is one of the simplest methods to calculate the trend of data in time series. The equation of the linear regression line is given in Equation 1.

$Y=a+b X$

Where:

$\mathrm{X}$ is the explanatory variable

$\mathrm{Y}$ is the independent variable ' $\mathrm{a}$ ' is the intercept (value of $\mathrm{y}$ when $\mathrm{x}=0$ ).

'b' is the slope [30]. 


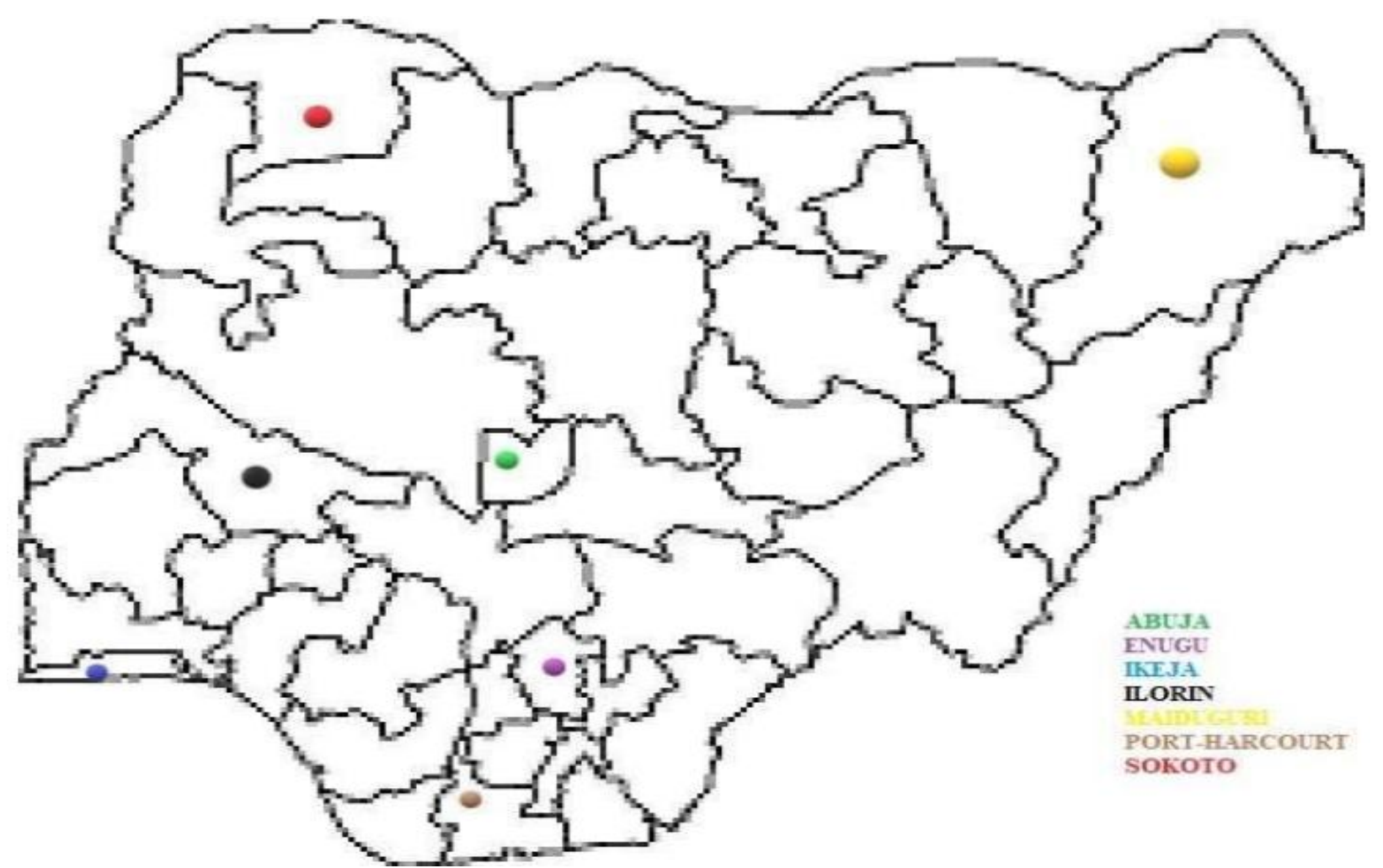

Green - Abuja Station, F.C.T.

Purple - Enugu Station, Enugu State.

Blue - Ikeja Station, Lagos State.

Black - Ilorin Station, Kwara State.

Yellow - Maiduguri Station, Borno State.

Brown- Port Harcourt Station

Rivers State. Red - Sokoto Station, Sokoto State.

Figure-1. Map of Nigeria showing study areas.

The slope of regression outlines the trend whether positive or negative. In this study independent variable, $\mathrm{Y}$ is rainfall, while the explanatory variable $\mathrm{X}$ is the month or year. Linear regression requires the assumption of normal distribution.

The regression line as a trend line in linear trend estimation is an application of linear regression. A trend line represents a trend, the long-term movement in time series data after the components have been accounted for. It shows whether a particular dataset has increased or decreased over the period. Trend lines typically are straight lines, although some variables use a higher degree of polynomials depending on the degree of curvature desired in the line. Linear trend estimation expresses data as a function of time. In this case, the null hypothesis is that the slope of the line is zero or there is no trend in the data. The pluviometry anomaly for the different stations was also calculated.

\section{RESULT AND DISCUSSION}

The time series plot of monthly rainfall at Abuja Figure 2, shows the outline of rainfall, which indicates the presence of seasonality in the maximum and minimum amount of rainfall in a year. The maximum rainfall experienced at Abuja in a month is $554.9 \mathrm{~mm}$ which occurred in the month of August of the year 1994. For a total of 343 months related to the analysis between 1982 to 2010, 92 months did not experience any rainfall. The months with a minimal record of rainfall are November, December, January, and February. A mean annual rainfall recorded was $1431.4 \mathrm{~mm}$ was experienced between 1982 and 2010. The trend line shows that there was an increase in the annual amount of rainfall experienced. 
Table-1. Annual Amount of Rainfall recorded for the 7 cities observation

\begin{tabular}{|c|c|c|c|c|c|c|c|}
\hline & Sokoto & Maiduguri & Ilorin & Abuja & Ikeja & PH & Enugu \\
\hline year & $\begin{array}{c}\text { Amount } \\
(\mathrm{mm}) \pm \mathrm{sd} \\
\end{array}$ & $\begin{array}{c}\text { Amount } \\
(\mathrm{mm}) \pm \mathrm{sd} \\
\end{array}$ & $\begin{array}{c}\text { Amount } \\
(\mathrm{mm}) \pm \mathrm{sd}\end{array}$ & $\begin{array}{c}\text { Amount } \\
(\mathrm{mm}) \pm \mathrm{sd} \\
\end{array}$ & $\begin{array}{c}\text { Amount } \\
(\mathrm{mm}) \pm \mathrm{sd}\end{array}$ & $\begin{array}{c}\text { Amount } \\
(\mathrm{mm}) \pm \mathrm{sd} \\
\end{array}$ & $\begin{array}{c}\text { Amount } \\
(\mathrm{mm}) \pm \mathrm{sd} \\
\end{array}$ \\
\hline 1980 & $558 \pm 65$ & $621 \pm 74$ & $1237 \pm 103$ & & $1686 \pm 111$ & $2544 \pm 157$ & $2091 \pm 176$ \\
\hline 1981 & $557 \pm 72$ & $461 \pm 62$ & $1287 \pm 143$ & & $1471 \pm 132$ & $2531 \pm 163$ & $1704 \pm 140$ \\
\hline 1982 & $569 \pm 95$ & $354 \pm 49$ & $1215 \pm 101$ & $1297 \pm 124$ & $1034 \pm 104$ & $2148 \pm 126$ & $1567 \pm 110$ \\
\hline 1983 & $619 \pm 82$ & $264 \pm 34$ & $1157 \pm 96$ & $1309 \pm 133$ & $895 \pm 98$ & $1808 \pm 136$ & $913 \pm 100$ \\
\hline 1984 & $467 \pm 56$ & $349 \pm 47$ & $1311 \pm 119$ & $1232 \pm 108$ & $1376 \pm 117$ & $2328 \pm 168$ & $1779 \pm 150$ \\
\hline 1985 & $427 \pm 52$ & $414 \pm 50$ & $1133 \pm 103$ & $1513 \pm 146$ & $1315 \pm 76$ & $2202 \pm 153$ & $1931 \pm 138$ \\
\hline 1986 & $476 \pm 64$ & $510 \pm 73$ & $1328 \pm 111$ & $1559 \pm 116$ & $1071 \pm 76$ & $2134 \pm 113$ & $1451 \pm 94$ \\
\hline 1987 & $373 \pm 40$ & $366 \pm 55$ & $1214 \pm 101$ & $1384 \pm 144$ & $1676 \pm 146$ & $2707 \pm 169$ & $1452 \pm 109$ \\
\hline 1988 & $697 \pm 91$ & $623 \pm 86$ & $899 \pm 75$ & $1241 \pm 96$ & $1940 \pm 160$ & $2209 \pm 128$ & $1461 \pm 108$ \\
\hline 1989 & $586 \pm 73$ & $610 \pm 69$ & $795 \pm 66$ & $1227 \pm 96$ & $1369 \pm 108$ & $1838 \pm 120$ & $1644 \pm 137$ \\
\hline 1990 & $654 \pm 103$ & $429 \pm 63$ & $1020 \pm 85$ & $1438 \pm 113$ & $1607 \pm 159$ & $2366 \pm 194$ & $2083 \pm 178$ \\
\hline 1991 & $772 \pm 78$ & $486 \pm 65$ & $1468 \pm 122$ & $1500 \pm 124$ & $1677 \pm 139$ & $2074 \pm 131$ & $1961 \pm 133$ \\
\hline 1992 & $549 \pm 67$ & $585 \pm 86$ & $932 \pm 78$ & $1377 \pm 105$ & $1131 \pm 113$ & $2201 \pm 155$ & $1707 \pm 115$ \\
\hline 1993 & $642 \pm 85$ & $491 \pm 70$ & $1158 \pm 96$ & $1529 \pm 130$ & $1646 \pm 75$ & $2597 \pm 219$ & $1578 \pm 120$ \\
\hline 1994 & $762 \pm 125$ & $453 \pm 56$ & $1242 \pm 104$ & $1626 \pm 167$ & $1205 \pm 83$ & $2422 \pm 154$ & $1456 \pm 109$ \\
\hline 1995 & $510 \pm 74$ & $689 \pm 94$ & $1409 \pm 117$ & $1309 \pm 126$ & $1630 \pm 84$ & $2437 \pm 153$ & $2168 \pm 150$ \\
\hline 1996 & $667 \pm 89$ & $631 \pm 74$ & $945 \pm 79$ & $1399 \pm 119$ & $1590 \pm 75$ & $2414 \pm 147$ & $1919 \pm 136$ \\
\hline 1997 & $646 \pm 71$ & $550 \pm 58$ & $1334 \pm 111$ & $1336 \pm 98$ & $2020 \pm 168$ & $1890 \pm 100$ & $2262 \pm 141$ \\
\hline 1998 & $846 \pm 119$ & $686 \pm 91$ & $1596 \pm 133$ & $1437 \pm 120$ & $1045 \pm 85$ & $2537 \pm 157$ & $1497 \pm 116$ \\
\hline 1999 & $712 \pm 97$ & $843 \pm 116$ & $1539 \pm 128$ & $1588 \pm 137$ & $1547 \pm 98$ & $2500 \pm 157$ & $1508 \pm 116$ \\
\hline 2000 & $720 \pm 106$ & $591 \pm 85$ & $990 \pm 83$ & $1198 \pm 106$ & $1299 \pm 125$ & $1977 \pm 152$ & $2018 \pm 143$ \\
\hline 2001 & $732 \pm 106$ & $728 \pm 95$ & $697 \pm 58$ & $1379 \pm 133$ & $1392 \pm 100$ & $2122 \pm 130$ & $1677 \pm 132$ \\
\hline 2002 & $769 \pm 84$ & $494 \pm 62$ & $902 \pm 75$ & $2021 \pm 182$ & $1795 \pm 128$ & $2071 \pm 158$ & $1722 \pm 130$ \\
\hline 2003 & $790 \pm 109$ & $653 \pm 87$ & $1034 \pm 103$ & $1706 \pm 159$ & $1518 \pm 103$ & $2468 \pm 151$ & $1891 \pm 151$ \\
\hline 2004 & $627 \pm 93$ & $757 \pm 100$ & $1294 \pm 118$ & $1540 \pm 127$ & $1694 \pm 112$ & $225 \pm 146$ & $1770 \pm 124$ \\
\hline 2005 & $633 \pm 68$ & $897 \pm 96$ & $1306 \pm 109$ & $1514 \pm 146$ & $1485 \pm 109$ & $2015 \pm 115$ & $1717 \pm ? 118$ \\
\hline 2006 & $740 \pm 101$ & $520 \pm 65$ & $1304 \pm 119$ & $1312 \pm 116$ & $1499 \pm 116$ & $2572 \pm 187$ & $2096 \pm 153$ \\
\hline 2007 & $636 \pm 83$ & $926 \pm 125$ & $1361 \pm 113$ & $1390 \pm 124$ & $1649 \pm 124$ & $2813 \pm 176$ & $1911 \pm 137$ \\
\hline 2008 & $515 \pm 58$ & $601 \pm 89$ & $1471 \pm 123$ & $1186 \pm 118$ & $1816 \pm 139$ & $1919 \pm 118$ & $1793 \pm 128$ \\
\hline 2009 & $601 \pm 63$ & $606 \pm 75$ & $1343 \pm 112$ & $1418 \pm 123$ & $1391 \pm 146$ & $2564 \pm 153$ & $1434 \pm 133$ \\
\hline 2010 & $1147 \pm 127$ & $662 \pm 87$ & $1193 \pm 99$ & $1548 \pm 131$ & $1655 \pm 111$ & $2488 \pm 119$ & $1697 \pm 123$ \\
\hline
\end{tabular}

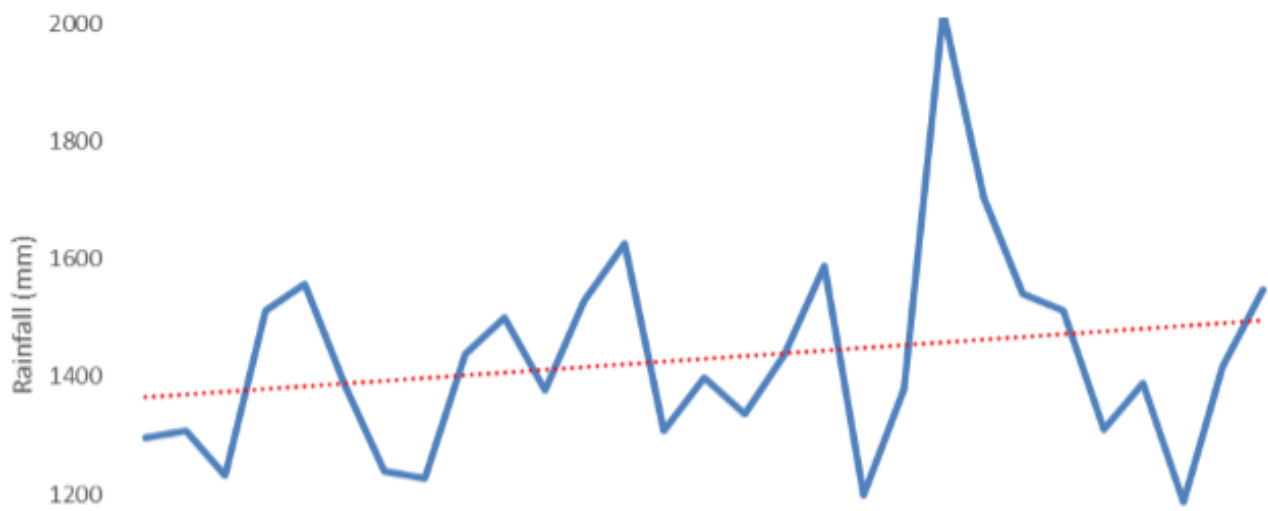

1000

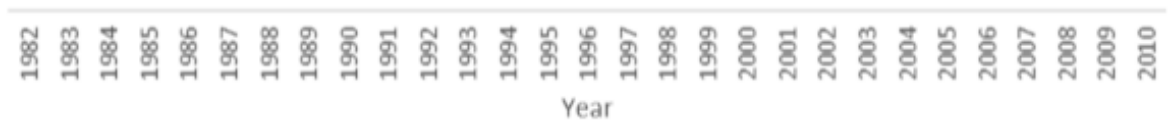

Figure-2. Rainfall at Abuja for the period $1982-2010$. 
The time series plot of monthly rainfall at Enugu is shown in the Figure 3. This explains the variation of rainfall at Enugu between 1980 to 2010, and indicates the presence of seasonality in the maximum and minimum amount of rainfall in a year. The maximum rainfall experienced at Enugu in a month was $508.3 \mathrm{~mm}$, which occurred in the month of July of the year 1990. A total of 372 months was analyzed, and a low number of 88 months experienced minimal rainfall, these include November, December, January, and February. A mean amount of rainfall of $1737.3 \mathrm{~mm}$ was experienced between 1980 to 2010 . In the year 1983, there was a serious dip recorded followed by series of variation. The trend line indicates an upward trend in the amount of rainfall occurring at Enugu.

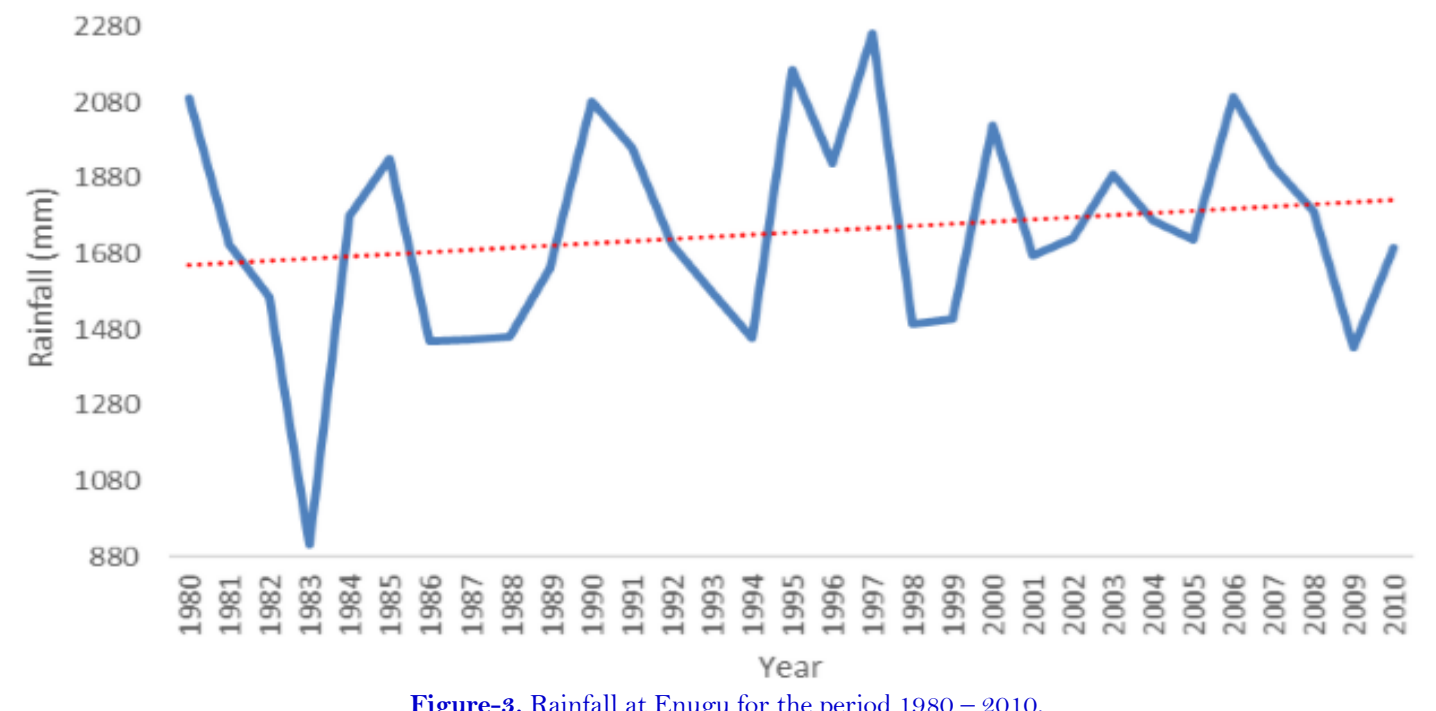

The time series plot of monthly rainfall at Ikeja is shown in Figure 4. It explains the variation of rainfall at Ikeja between the years 1980 to 2010 . This indicates the presence of seasonality in the maximum and minimum amount of annual rainfall. The maximum rainfall experienced at Ikeja a month was $619.5 \mathrm{~mm}$, which occurred in the month of June in the year 1997. Out of the 372 months considered, a low number of 29 months didn't record any rainfall. A mean rainfall amount of $1487.8 \mathrm{~mm}$ was recorded between the years 1980 to 2010 . The trend line shows an upward trend in the amount of rainfall occurring at Ikeja.

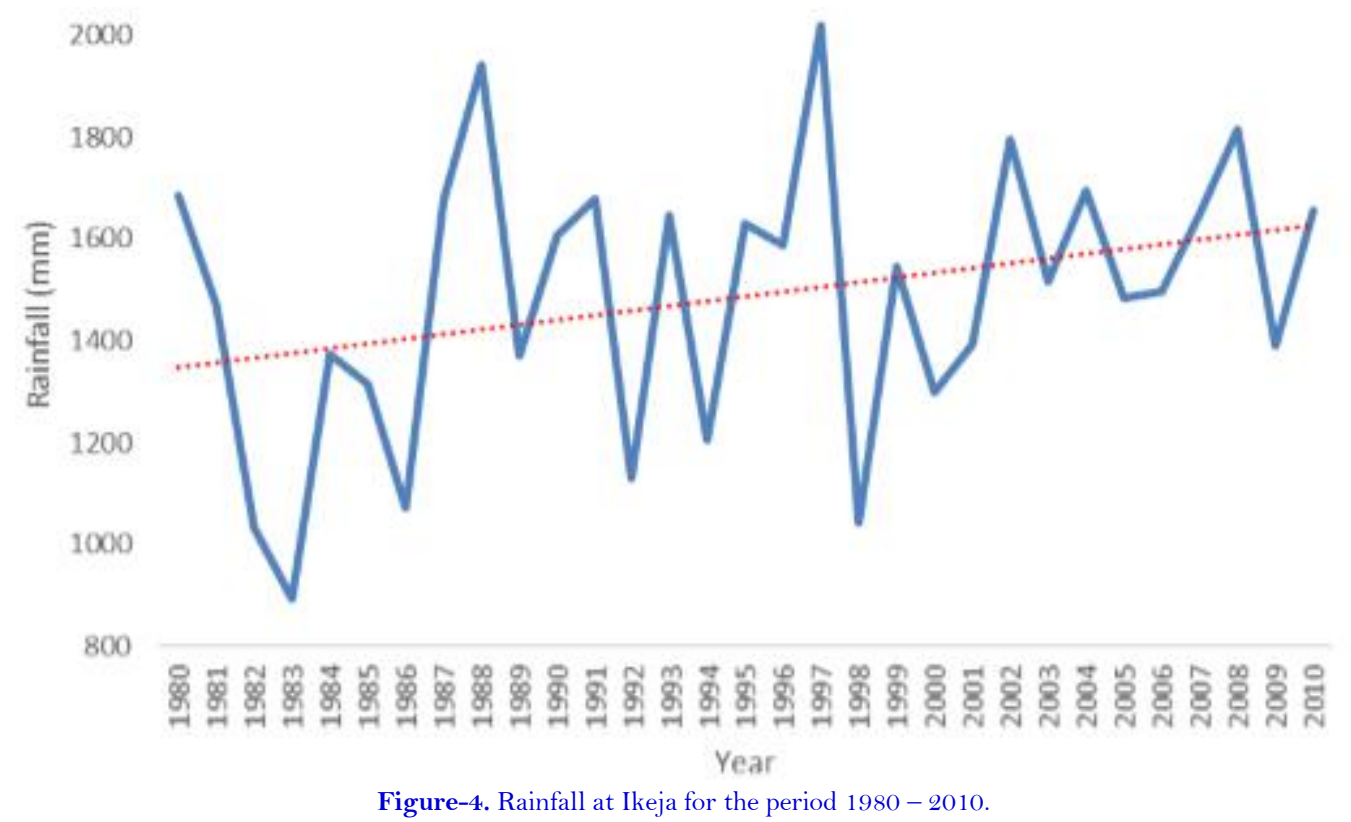


Figure 5 shows the time series plot of monthly rainfall at Ilorin. It indicates the variation of rainfall at Ilorin between the years 1980 to 2010 . This explains the presence of seasonality in the maximum and minimum amount of rainfall in a year. The maximum rainfall experienced at Ilorin in a month was $370.8 \mathrm{~mm}$, which occurred in the month of June in the year 2003. From the 372 months considered, 76 months experienced little or no rainfall. These months include November, December, January, and February. A mean annual amount of 1197.2mm of rainfall was recorded between the years 1980 to 2010 . The trendline shows a slight upward trend in the amount of rainfall. As a result, flooding has become a frequent occurrence in Ilorin wrecking a lot of havoc. Communities that are located on lower elevations and those built on floodplains are usually the ones affected [31].

llorin

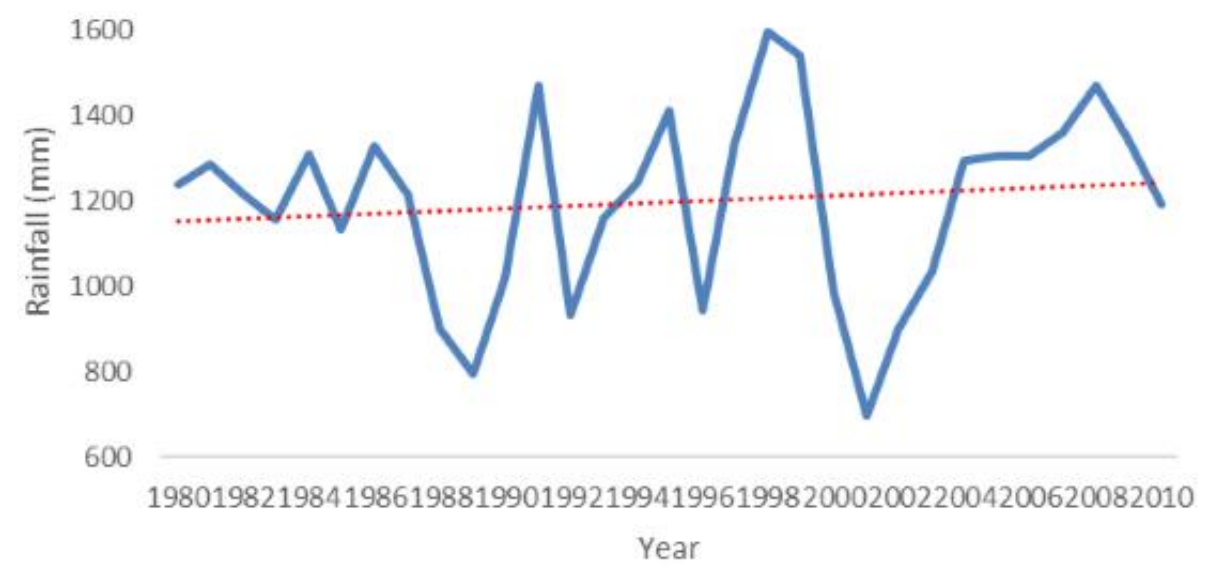

Figure-5. Rainfall at Ilorin for the period $1980-2010$.

Figure 6 shows the variation in rainfall at Maiduguri between 1980 and 2010, this illustrates the presence of seasonality in the highest and least amount of rainfall in a year. 372 months were analyzed, 173 months experienced little or no rainfall (November, December, January, and February make up these months). The maximum rainfall experienced at Maiduguri in a month was $296.4 \mathrm{~mm}$. Between 1980 and 2010, there was an annual average amount of $575.7 \mathrm{~mm}$ of rain. The trend line show that there was a large increase in the amount of rainfall experienced in Maiduguri. This is proved by the flood which occurred in the city of Maiduguri in the year 1994. It was reported by the United Nations Department of Humanitarian Affairs (UNDHA) that on the $13^{\text {th }}$ of September 1994 that "Alau" Dam broke its banks as a result of excessive rainfall, hence causing one of the biggest Flood scenario in the history of Maiduguri [32].

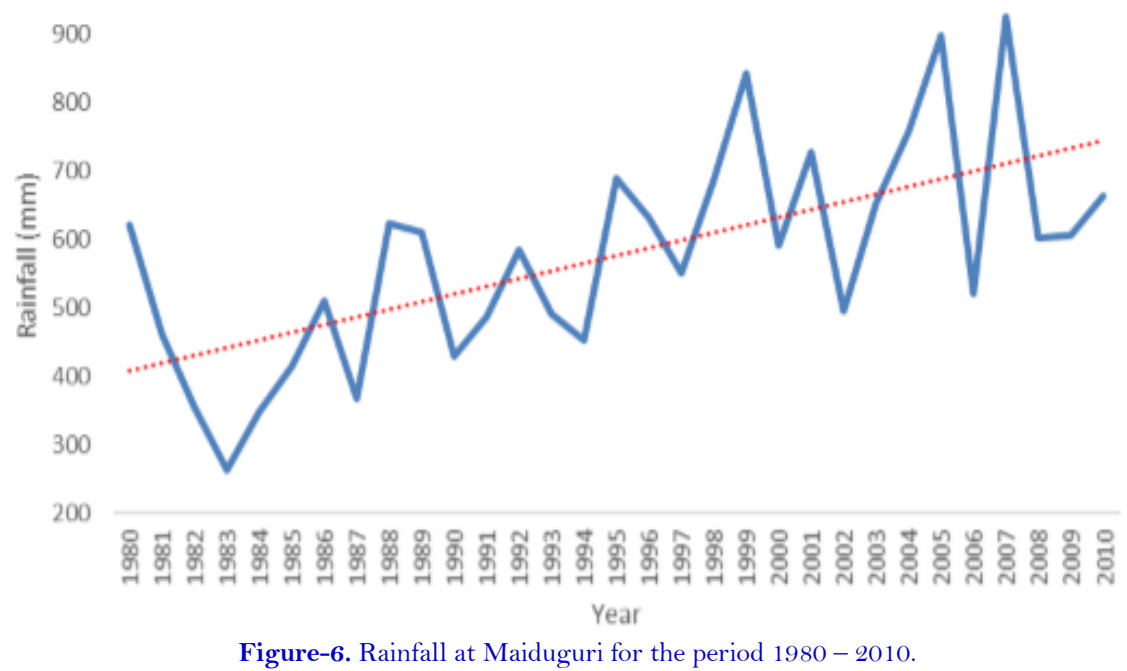


The time series plot of monthly rainfall at Port-Harcourt is shown in the Figure 7. It explains the variation of rainfall at Port-Harcourt between the years 1980 to 2010. This indicates the presence of seasonality in the maximum and minimum amount of annual rainfall. The maximum rainfall experienced at Port-Harcourt a month is $776.7 \mathrm{~mm}$, which occurred in the month of July in the year 1993. 372 months were considered, a low number of 18 months experienced little or no rainfall. An average of $197.6 \mathrm{~mm}$ rainfall was experienced per month between the years 1980 and 2010. The trend line showed that there was a slight increase in the rainfall amount experienced over the years at Port-Harcourt. In 2006, it was reported that Port Harcourt experienced an uncommon type of flooding in which houses were submerged, economic activities experienced a crash, and a lot of people became internally displaced in some zones [33].

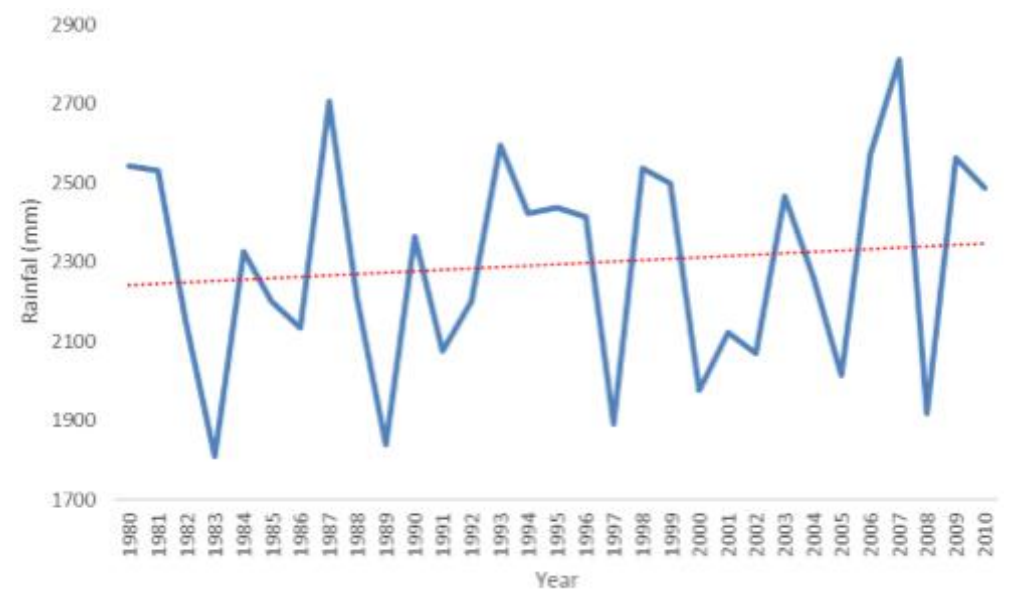

Fgure-7. Rainfall at Port-Harcourt for the period $1980-2010$.

Figure 8 shows the variation of rainfall at Sokoto between the years 1980 and 2010, which indicates the presence of seasonality in the maximum and minimum amount of rainfall annually. Of the 372 months considered, 183 months experienced little or no rainfall, the maximum rainfall experienced at Sokoto in a month is $355.6 \mathrm{~mm}$. An average amount of $645 \mathrm{~mm}$ rainfall was experienced between 1980 and 2010 . To support the trend shown by the trendline, it was reported that in the year 2007 that over 5000 people were displaced due to the flood experienced. It was stated in the report that a Sokoto State Emergency Services' official stated that the city of Sokoto has not experienced this kind of flood in many years [34].

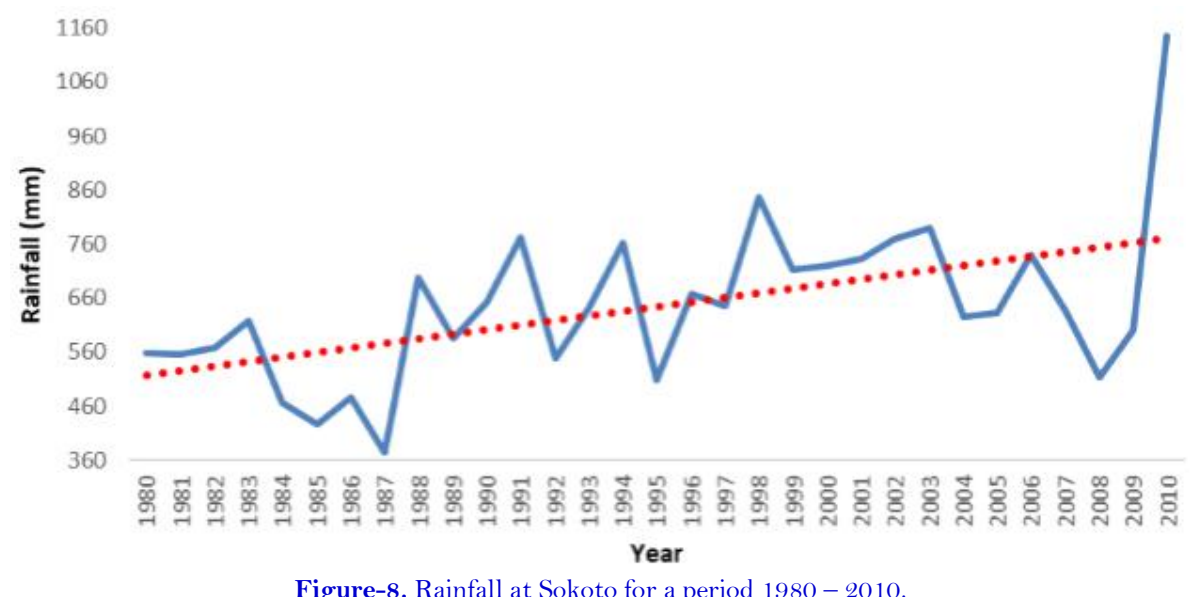

From Figures 9 i and ii, shows the monthly and yearly rainfall anomalies respectively which was experienced at Abuja for a period of 1982 - 2010. Observations were made that the negative deviation of rainfall that occurred in non-rainfall months (November - April) was the same as the positive deviation of recorded rainfall for rainfall 
months (May to October). But for the years, it is observed that between 1980 to 2010, the negative deviation of rainfall was less prominent than the positive.
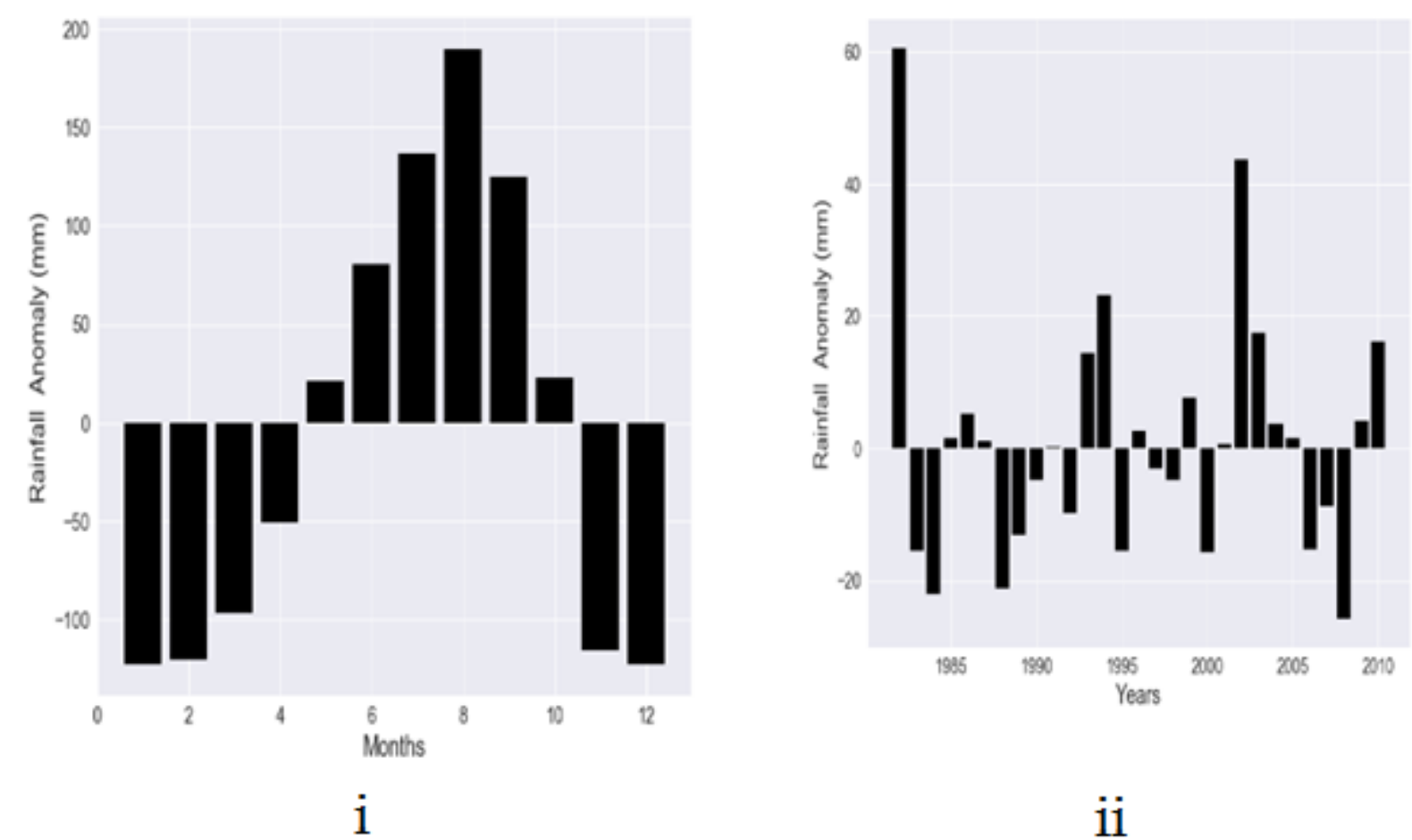

Figure-9. Rainfall anomalies at Abuja.

Figure $10 \mathrm{i}$ and ii shows the plot of monthly and yearly anomalies respectively, recorded at Enugu for the period of observation. It was observed that the negative deviation of non-rainfall months was less than the positive deviation of rainfall months (April to October). For the years, it was observed that between 1980 to 2010, the negative deviation was more prominent than the positive.
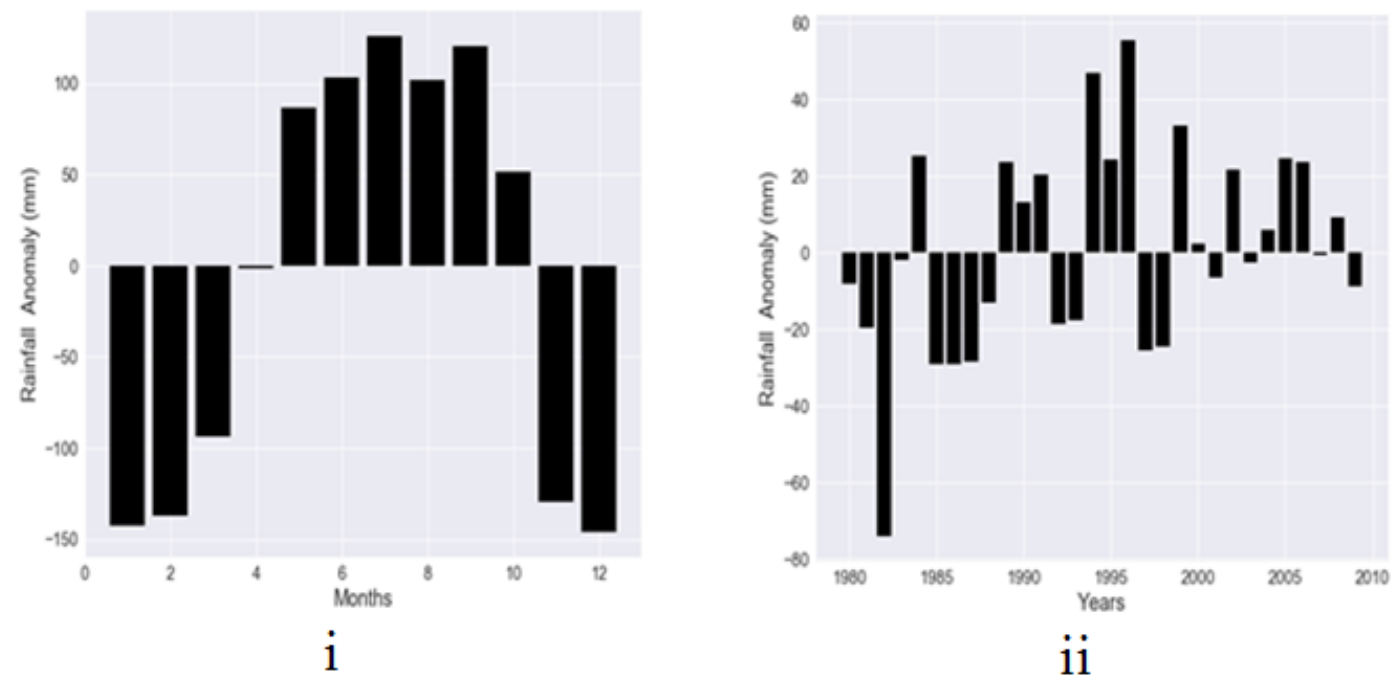

Figure-10. Rainfall anomalies at Enugu.

The Figures $11 \mathrm{i}$ and ii shows the respective monthly and yearly rainfall anomalies recorded during the period under observation for Ikeja. it was observed that the negative deviation of non-rainfall months (November - March, and August) was the same as the positive deviation of those that experienced rainfall (April, May, June, July, 
September, and October). For the years, it was observed that between 1980 to 2010, the negative deviation of rainfall was less prominent than the positive.
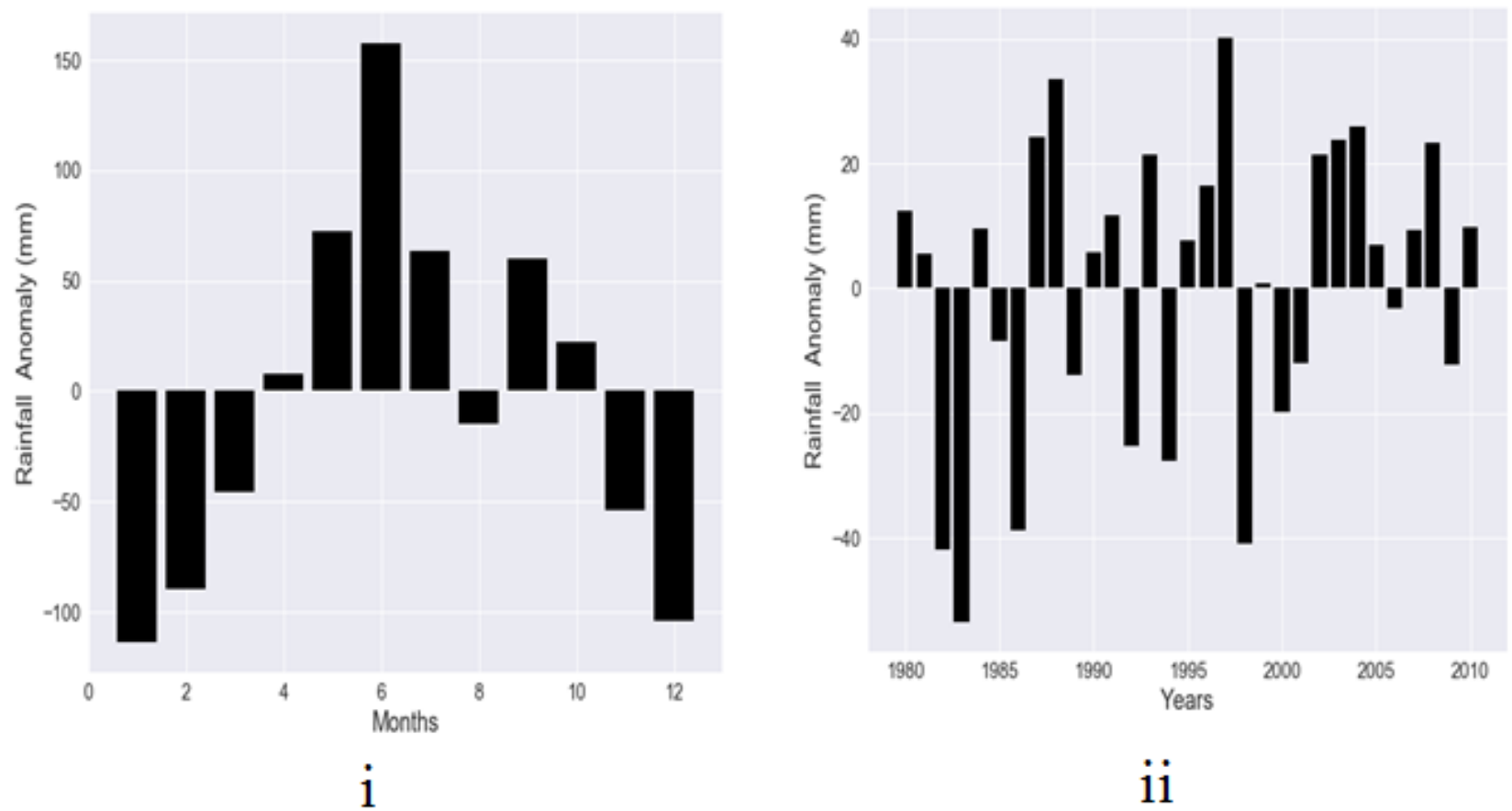

Figure-11. Rainfall anomalies at Ikeja.

From Figure $12 \mathrm{i}$ and ii which shows the monthly and yearly rainfall anomalies respectively, recorded for the observation period, the negative deviation of rainfall for non-rainfall months (November - April) was the same with the positive deviation of rainfall for rainfall months (May - October). For the annually situation, it was observed that between the years 1980 to 2010 , the negative deviation of rainfall was less prominent than the positive.
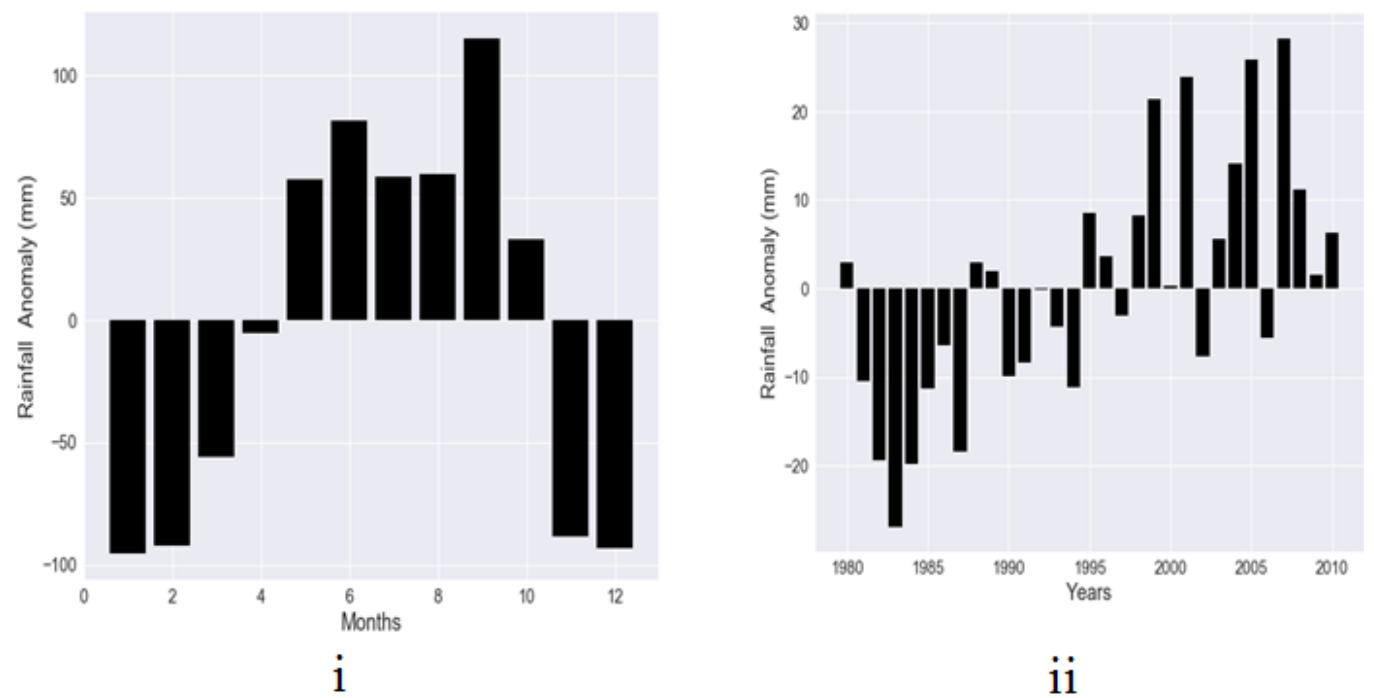

Figure-12. Rainfall anomalies at Ilorin.

Figure 13 shows the respective monthly and yearly rainfall anomalies recorded at Maiduguri. From figure $13 \mathrm{i}$ and ii, it was observed that the negative deviation of rainfall recorded for the non-rainfall months was more than the positive deviation of rainfall for rainfall months (June to September). For the years, it was observed that between 1980 to 2010 , the negative anomaly of rainfall was less prominent than the positive anomaly of rainfall. 


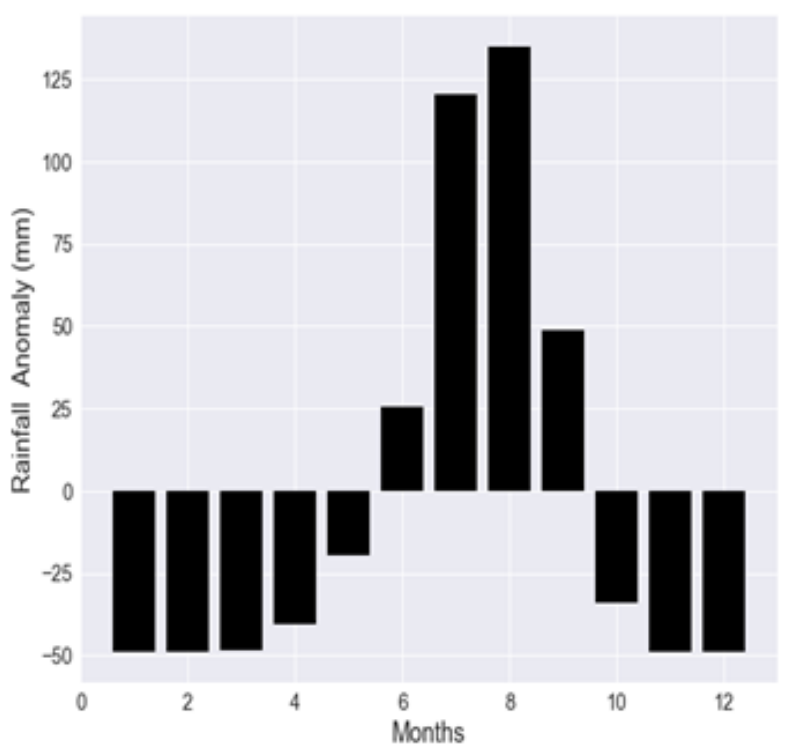

i

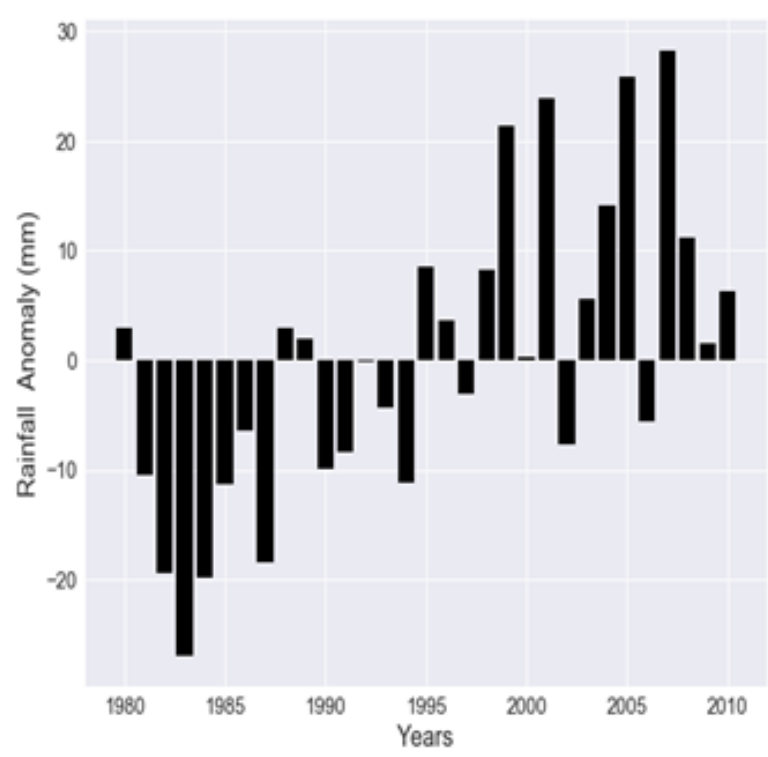

ii

Figure-13. Rainfall anomalies at Maiduguri.

Figure 14 represents the plot of both monthly and yearly rainfall anomalies. From figure $14 \mathrm{i}$ and ii, the negative deviation of rainfall that occurred in non-rainfall months (November to April) was equally as prominent as the positive deviation of rainfall that occurred in rainfall months (May to October), was the same. It was observed for the years that between the years 1980 to 2010, the negative anomaly of rainfall was less prominent than the positive anomaly of rainfall.

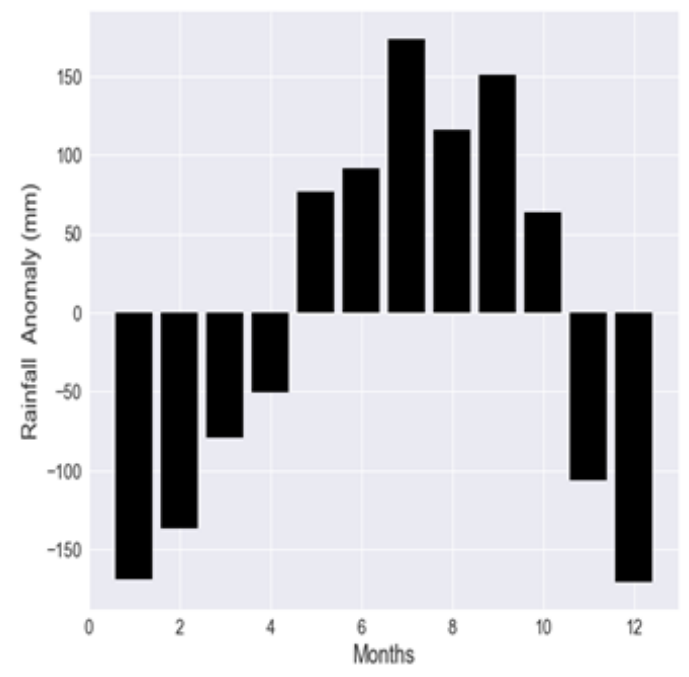

i

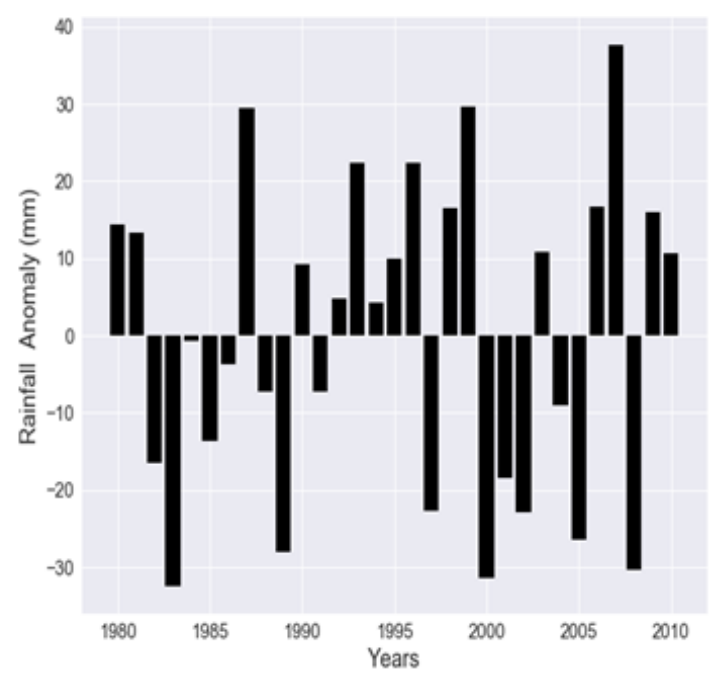

ii

Figure-14. Rainfall anomalies at Port-Harcourt.

From the Figure $15 \mathrm{i}$ and ii which shows the respective plot of monthly and yearly rainfall anomalies recorded in the city of Sokoto, the negative deviation of rainfall that occurred in non-rainfall months (October - May) was less than the positive deviation of rainfall that occurred in rainfall months (June - September). It was observed for the years that between 1980 to 2010, the negative anomaly of rainfall was as prominent as the positive anomaly of rainfall. 


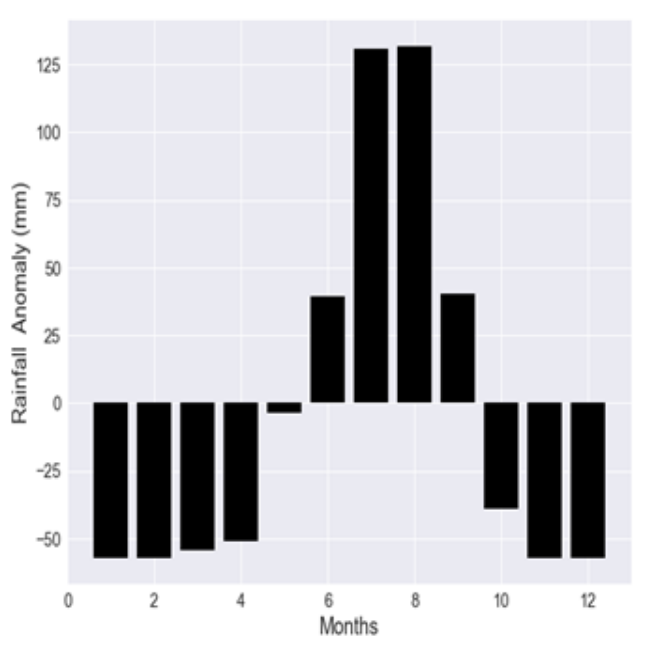

i

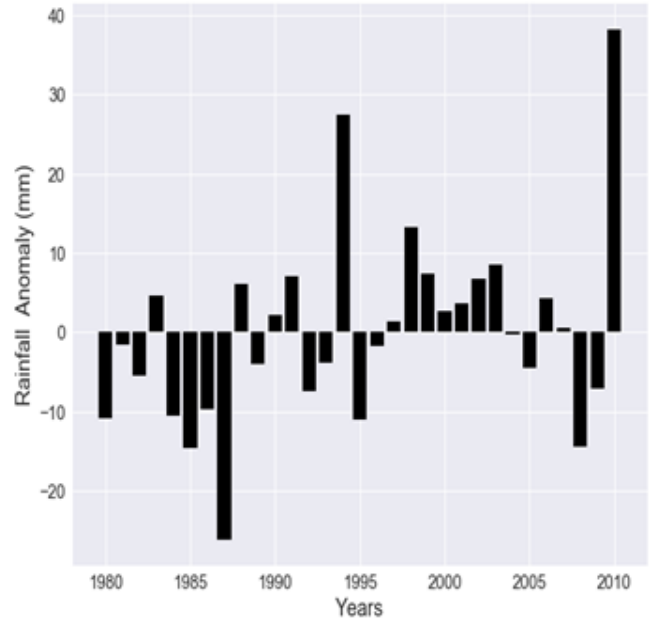

ii

Figure-15. Rainfall anomalies at Sokoto.

The cause of these fluctuation in the amount of rainfall across these study areas is attributed to the increasing impact of climate change. This is majorly caused by the increase in anthropogenic activities in these areas, which is as a result of the increased influx of people into these areas from neighboring rural areas.

\section{CONCLUSION}

In conclusion, this study analysed the trend of rainfall over the period of 31 years for some seven cities from the six (6) geographical zones of the country. It was discovered that for the 31 years studied, all the study areas experienced an increase in the trend of rainfall. While some areas (areas in the core north) experienced a great increase in the trend of rainfall, other areas (areas in the coastal region) experienced a slight increase in the trend of rainfall. This indicates that the annual variability was somewhat a common feature in the study areas. This increase is proven by the frequent occurrence of flood in these areas, places that do not experience enough rainfall a while back now experience rainfall on a frequent basis. This is attributed to climate change which has increased the rate at which precipitation is received in some parts of the world and reduced it elsewhere. The flood caused by the increase in rainfall over the years has caused a lot of havoc such as loss in farm produce, loss of lives and properties etc. A lot of research should be done in order to help us as a country find a way to live with this new normal.

Funding: This study received no specific financial support.

Competing Interests: The authors declare that they have no competing interests.

Acknowledgement: All authors contributed equally to the conception and design of the study.

\section{REFERENCES}

[1] X. Wen, X. Wu, and M. Gao, "Spatiotemporal variability of temperature and precipitation in Gansu Province (Northwest China) during 1951-2015," Atmospheric Research, vol. 197, pp. 132-149, 2017.Available at: https://doi.org/10.1016/j.atmosres.2017.07.001.

[2] M. S. Shiru, S. Shahid, E.-S. Chung, N. Alias, and L. Scherer, "A MCDM-based framework for selection of general circulation models and projection of spatio-temporal rainfall changes: a case study of Nigeria," Atmospheric Research, vol. 225, pp. 1-16, 2019.Available at: https://doi.org/10.1016/j.atmosres.2019.03.033.

[3] X. Zhang, E. Aguilar, S. Sensoy, H. Melkonyan, and M. Semawi, "Trends in middle east climate extreme indices from 1950 to 2003," Journal of Geophysical Research: Atmospheres, vol. 110, pp. 3159-3172, 2005.Available at: https://doi.org/10.1029/2005jd006181. 
[4] J. Scalzitti, C. Strong, and A. Kochanski, "Climate change impact on the roles of temperature and precipitation in western US snowpack variability," Geophysical Research Letters, vol. 43, pp. 5361-5369, 2016.Available at: https://doi.org/10.1002/2016glo68798.

[5] Y. Xu, Y. Wang, L. Wu, G. Li, and S. Song, "Spatial and temporal trends of reference crop evapotranspiration and its influential variables in Yangtze River Delta, eastern China," Theor. Appl. Climatol, vol. 130, pp. 1-14, 2016.

P. C. D. Milly, R. T. Wetherald, K. Dunne, and T. L. Delworth, "ncreasing risk of great floods in a changing climate," Nature, vol. 415, pp. 514-517, 2002.

R. Wang, J. Chen, X. Chen, and Y. Wang, "Variability of precipitation extremes and dryness/wetness over the southeast coastal region of China, 1960-2014," International Journal of Climatology, vol. 37, pp. 4656-4669, 2017.Available at: https://doi.org/10.1002/joc.5113.

IPCC, Impacts, adaptation, and vulnerability. In: Part B: Regional Aspects-Contribution of Working Group II to the Fifth Assessment Report of the Intergovernmental panel on climate change. Cambridge, UK and New York: Cambridge University Press, 2014.

[9] S. S. Bruno, F. D. José, A. Fabiano, G. Givanildo, G. M. J. João, M. T. Paulo, R. P. Edison, B. L. Gustavo, and Z. Marcelo, "PERSIANN-CDR based characterization and trend analysis of annual rainfall in Rio De Janeiro State, Brazil," Atmospheric Research, vol. 238, p. 104873, 2020.Available at: https://doi.org/10.1016/j.atmosres.2020.104873.

[10] S. B. Ogungbenro and T. E. Morakinyo, "Rainfall distribution and change detection across climatic zones in Nigeria," Weather and Climate, vol. 5, pp. 1-6, 2014.Available at: https://doi.org/10.1016/j.wace.2014.10.002.

[11] O. Ideki and V. Weli, "Analysis of rainfall variability using remote sensing and GIS in North Central Nigeria," Atmospheric and Climate Sciences, vol. 9, pp. 191-201, 2019.Available at: https://doi.org/10.4236/acs.2019.92013.

[12] IPCC, "Climate Change 2007: Impacts, Adaptation, and Vulnerability. In: Annex, I., Parry, M.L., Canziani, O.F., Palutikof, J.P., van der Linden, P.J. and Hanson, C.E., Eds., contribution of working group II to the fourth assessment Report of the intergovernmental panel on," ed Cambridge University Press, Cambridge: Climate Change, 2007, p. 976.

[13] M. O. Kisaka, M. Mucheru-Muna, F. Ngetich, D. Mugendi, and M. F., "Seasonal rainfall variability and drought characterization: Case of eastern arid region of Kenya. In: Leal Filho, W., Esilaba, A., Rao, K. and Sridhar, G., Eds., Adapting African Agriculture to Climate Change," ed Cham: Springer, 2015, pp. 53-71.

[14] IPCC Sixth Assessment, "TAR climate change, impacts, adaptation, and vulnerability. Retrieved from: https://www.ipcc.ch/report/ar3/wg2/," 2001.

[15] M. T. Daramola, E. O. Eresanya, and S. C. Erhabor, "Analysis of rainfall and temperature over climatic zones in Nigeria," Journal of Geography, Environment and Earth Science International, vol. 11, pp. 1-14, 2017.Available at: https://doi.org/10.9734/jgeesi/2017/35304.

[16] I. B. David, "Eclectic climatology," Yearbook of the Association of Pacific Coast Geographers, vol. 30, pp. 175-179, 1986.

[17] United States Department of Agriculture, Food security assessment, 2010-20. Report GFA-21. Washington DC: Economic Research Service, 2010.

[18] T. F. Stocker, D. Qin, G. K. Plattner, M. Tignor, S. K. Allen, J. Boschung, and P. M. Midgley, "Technical summary. Climate change 2013: The physical science basis," Contribution of Working Group I to the Fifth Assessment Report of the IPCC2013.

[19] S. Braide, W. Izonfuo, P. Adiukwu, A. Chindah, and C. Obunwo, "Water quality of Miniweja stream, a swamp forest stream receiving non-point source waste discharges in Eastern Niger Delta, Nigeria," Scientia Africana, vol. 3, pp. 1-8, 2004.

[20] A. C. Chindah, "Response of periphyton community to sanity gradient in tropical estuary, Niger Delta," Polish Journal Ecology, vol. 52, pp. 83-89, 2004.

[21] A. B. Chinago, "Analysis of rainfall trend, fluctuation and pattern over port harcourt, Niger Delta coastal environment of Nigeria," Biodiversity International Journal, vol. 4, pp. 1-8, 2020.Available at: https://doi.org/10.15406/bij.2020.04.00158. 
[22] A. Gobo, "Rainfall data analysis as an aid for designs for maximum drainage and flood control works in Port Harcourt," discovery and Innovation, vol. 2, pp. 25-31, 1990.

[23] I. R. Abubakar, "Abuja city profile, Cities," vol. 41, pp. 81-91, 2014.

[24] T. Itiowe, A. V., and M. H. S., "Analysis of rainfall trends and pattern in Abuja, Nigeria," Journal of Applied Science and Technology, vol. 34, pp. 1-7, 2019.Available at: https://doi.org/10.9734/cjast/2019/v34i430139.

[25] O. T. Kolebaje, A. Ikusika, and A. P., "Estimating solar radiation in Ikeja and port harcourt via correlation with relative humidity and temperature," Journal of Energy Production and Management, vol. 1, pp. 253-262, 2016.Available at: https://doi.org/10.2495/eq-v1-n3-253-262.

[26] E. A. Iyi, "A review of Enugu (Enugu State, Nigeria) urban growth and development," Journal of Research in Environmental and Earth Sciences, vol. 1, pp. 44-51, 2014.

[27] V. U. Okwu-Delunzu, I. C. Enete, A. S. Abubakar, and L. S., "Monitoring gully erosion at nyaba river, enugu state, Southeastern Nigeria, using remote sensing," SPIE Proceeding, vol. 8887, 2013.Available at: https://doi.org/10.1117/12.2035967.

[28] C. Igwenagu, "Trend analysis of rainfall pattern in Enugu State, Nigeria," European Journal of Statistics and Probability, vol. 3, pp. 12-18, 2015.

[29] O. J. Olaniran, "Rainfall anomalies: The contemporary understanding," presented at the 55th Inaugural Lecture Series, University of Ilorin, Ilorin, Nigeria, 2002.

[30] N. S. Abeysingha, M. Singh, V. K. Sehgal, M. Khanna, and H. Pathak, "Analysis of rainfall and temperature trend in Gomti River basin," Journal of Agricultural Physics, vol. 14, pp. 56-66, 2014.

[31] M. S. Shiru, L. M. Johnson, O. U. Ujih, and O. T. AbdulAzeez, "Managing flood in ilorin, Nigeria: Structural and non structural measures," Asian Journal of Applied Sciences, vol. 3, pp. 507-513, 2015.

[32] Nigeria Floods Sep 1994, "Nigeria floods sep 1994 UN DHA situation reports 1 - 3, DHA-GENEVA 94/0361, published on 22 Sept., 1994. Retrieved from: https://reliefweb.int/report/nigeria/nigeria-floods-sep-1994-un-dhasituation reports-1-3," 1994.

[33] N. Zabbey, "Flood hazard vulnerabilities and coping strategies of residents of urban settlements in Metro Manila, the Philippines”. In D. J. Parker (Ed.), Floods," London, England: Routledge, 2006, pp. 69-88.

[34] The New Humanitarian, "Nigeria: With new flooding in Sokoto, 50,000 people displaced nationwide, published on 5 sept., 2007, Retrieved from: https://reliefweb.int/report/nigeria/nigeria-new-flooding-sokoto-50000-peopledisplaced-nationwide," 2007.

Views and opinions expressed in this article are the views and opinions of the author(s), International Journal of Climate Research shall not be responsible or answerable for any loss, damage or liability etc. caused in relation to/arising out of the use of the content. 